\title{
Impacts of Heavy Metals on Soil Microbial Activity
}

\author{
Ana Paula Justiniano Régo (Corresponding author) \\ Center of Nuclear Energy in Agriculture, University of São Paulo \\ Avenue: Centenário, n. 303. Piracicaba, SP, 13400-970, Brazil
}

Tel: 55 (19) 3429-4765 E-mail: justiniano@usp.br

\author{
Valdemar Luiz Tornisielo \\ Center of Nuclear Energy in Agriculture, University of São Paulo \\ Avenue: Centenário, n. 303. Piracicaba, SP, 13400-970, Brazil \\ Tel: 55 (19) 3429-4762 E-mail: vltornis@cena.usp.br
}

Received: August 14, 2019 Accepted: February 8, 2020 Published: February 11, 2020

doi:10.5296/jee.v11i1.16444

URL: https://doi.org/10.5296/jee.v11i1.16444

\begin{abstract}
Concern about soil quality has been increasing due to environmental impacts from anthropogenic actions. The imbalance between its components alters activities in ecosystems. One of the main actions affecting soil quality is the presence of heavy metals, impairing the functioning of the ecosystem. This work evaluated the impacts of metal-contaminated soil on microbial activity after dam failure in Minas Gerais State, Brazil. Microbial respiration measurements and colony quantifications were used for evaluations. Thus, it is hoped that through these bioindicators, we can assess the quality of the environment and from these biostimulators restore the environmental balance, benefiting local communities affected by the disaster. After microbial biostimulation of the soil, there was an increase in the number of bacterial colonies as well as greater accumulation of $\mathrm{CO}_{2}$ over the days. Thus, the addition of nutrients to the metal-impacted soil was essential for initiating the restoration of the affected ecosystem equilibrium.
\end{abstract}

Keywords: Microorganisms, Contamination, Environmental imbalance

\section{Introduction}

The sources of heavy metal pollution can be of natural or anthropogenic origin, coming from mining, industrialization or agriculture, being mining one of the most important sources of origin (Li et al., 2014). 
Heavy metals interfere with the quality of the environment, water bodies, threats to the health and welfare of animals and humans through the food chain, and can lead to diseases such as cancer, renal dysfunction, hypertension, among others (Tchounwou et al., 2012).

Microorganisms have the ability to pick up heavy metals, either by bioaccumulation or by adsorption, from the microbial cell wall, which contains lipids, proteins, and some functional groups. However, the presence of heavy metals in the environment results in a decrease in the microbial population, due to the high toxicity of the elements, so it is necessary to use alternatives in order to keep the microbial population healthy (Chen et al., 2015).

Rathnayake et al. (2013) observed that the presence of cadmium and copper metals in soil reduced for the metabolic activity of Bacillus megaterium, B. thuringiensis and B. simplex.

Thus, in recent years, soil quality studies have been increasing due to the aggravation of environmental problems. Quality is related to the balance of all its elements, as well as its ability to maintain high productivity, causing minimal environmental disruption (Duval et al., 2013).

The indices for soil quality assessment should be sensitive to changes and easily determined (Armenise et al., 2013). Must be part of the physical, chemical and biological properties (Andrews et al., 2004). Bioindicators are species and / or biological activities that reveal the environmental condition of a given location that may come from anthropic actions (Baretta et al., 2006; Baretta et al., 2011; Kladivko et al., 2014).

Thus, looking for sustainable alternatives, biofertilizer has organic compounds and microorganisms capable of assisting in these factors, in a sustainable way and with low production cost (Aseri et al., 2008; D’andrea, 2002; Vessey, 2003; Wu et al., 2005).

Medina et al. (2012) studied the effects of the application of nutrient rich organic compounds in hydrocarbon contaminated soils, concluding that this practice favored the degradation of the contaminants.

In soil contaminated with the pesticide amethrin, the application of biofertilizer favored microbial activity, as measured by soil respiration, using the Bartha and Pramer respirometry technique, observed by Régo et al. (2014).

Thus, with its rich nutrient composition and wide use in various crops, it makes biofertilizer an alternative for use in soil xenobiotic degradation, improving soil quality (Jilani et al., 2007; Régo et al., 2014).

Also as a second sustainable alternative is the use of biochar for the removal of metal ions in water. It is a solid material obtained through the carbonization of biomass. It can be used to replace activated charcoal or coconut shell as a low cost and easily obtainable adsorbent to remove contaminants from water (Lehmann et al., 2011; Mohan et al., 2014).

The objective of this work was to evaluate the effects of heavy metals on soil microbial activities following the disaster that occurred in the city of Mariana, Minas Gerais State, Brazil, caused by the disruption of the Fundão dam, which resulted in the release of 34 million $\mathrm{m}^{3}$ of mud from iron ore production by mining company Samarco, which is controlled by Vale and Britain's BHP Billiton. The fact occurred in november 2015. 


\section{Methodology}

It collected metal contaminated mud in the city of Mariana, as well as collecting soil without the passage of mud, in a region near the city of Mariana, in Brazil.

In order to evaluate the microbial activity of contaminated soils, colony forming units per gram of soil were quantified by pour plate technique and the evaluation of respiration by $\mathrm{CO}_{2}$ generation over time. The treatments consisted of:

- $\quad 0 \%-50.0 \mathrm{~g}$ control soil + nutrients

- $\quad 25 \%-12.5 \mathrm{~g}$ metal soil + nutrients

- $\quad 50 \%-25.0$ g metal soil + nutrients

- $\quad 75 \%-37.5 \mathrm{~g}$ metal soil + nutrients

- $100 \%-100.0 \mathrm{~g}$ metal soil + nutrients

- $\quad 50.0 \mathrm{~g}$ control soil

- $\quad 50.0 \mathrm{~g}$ control metal soil

For microbial biostimulation, bacteria selected from soil samples containing metals were used, together with $100 \mathrm{~mL}$ minimum medium enriched with coffee husk. After growth, $5 \mathrm{~mL}$ was inoculated into $50.0 \mathrm{~g}$ of dry soil.

\subsection{Microbial Quantification}

The quantification of the microbial population was performed by the plating technique in order to quantify the number of bacterial and fungal colonies per gram of soil. The culture media PCA (Plate Count Agar) for bacteria and PDA (Potato Dextrose Agar) for fungi were used and placed in sterile Petri dishes.

By means of $0.85 \%(\mathrm{w} / \mathrm{v})$ sodium chloride $\mathrm{NaCl}$ solution, soil dilutions were made for counting colony forming units. $0.85 \mathrm{~g}$ of dissolved $\mathrm{NaCl}$ was weighed $100 \mathrm{~mL}$ of deionized water. After preparation, $6 \mathrm{~mL}$ of the solution was placed in test tubes for later sterilization.

$50.0 \mathrm{~g}$ of soil was weighed into a $250 \mathrm{~mL}$ schott flask and $50.0 \mathrm{~mL}$ of deionized water was added for stirring at $200 \mathrm{rpm}$ for 1 hour on a shaking table. After this period, the flasks were allowed to stand for $30 \mathrm{~min}$ and only the supernatant formed was used to start plating.

Plates were incubated for 72 hours at $28{ }^{\circ} \mathrm{C}$ for fungi, and for 48 hours at $35{ }^{\circ} \mathrm{C}$ for bacteria. After the incubation period, the readings of the forming colony units were performed per gram of soil.

\subsection{Microbial Respiration}

By Bartha and Pramer respirometers (1965), $\mathrm{CO}_{2}$ generation over time was evaluated. The tests will be based on OECD (2002).

The $\mathrm{CO}_{2}$ from microbial respiration will react with the sodium hydroxide solution over time. At times, aliquots of sodium hydroxide will be taken to be titrated with hydrochloric acid to quantify the generation of $\mathrm{CO}_{2}$ over that period. The spent volume of hydrochloric acid will be entered into the following equation: (1): 
$\mathrm{CO}_{2}=(\mathrm{A}-\mathrm{B}) \times 50 \times \theta_{\mathrm{HCl}} \times 0.044$

Being that:

$\mathrm{A}=\mathrm{HCl}$ volume spent for control

$\mathrm{B}=\mathrm{HCl}$ volume spent for treatments

$\theta_{\mathrm{HCl}}=$ Normality factor $\mathrm{HCl}$

50 e $0.044=$ Transformation factor from $\mu \mathrm{mol}$ to $\mathrm{mg}$ of $\mathrm{CO}_{2}$

\section{Results and Discussion}

Microbial biostimulation was essential for increasing metabolic activities, both in increasing the number of colonies (Figure 1) and in increasing the accumulation of $\mathrm{CO}_{2}$ over the days (Figure 2). For the soil control treatment, there was a growth of $42 \pm 3 \mathrm{CFU} \mathrm{g}{ }^{-1}$, and for the metal soil there was $40 \pm 2 \mathrm{CFU} \mathrm{g}^{-1}$.

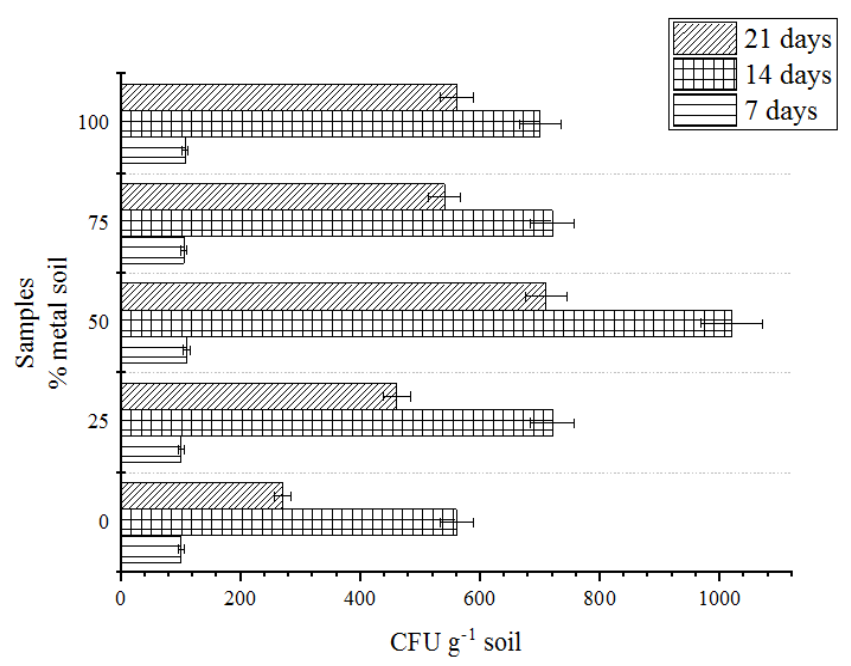

Figure 1. Quantification of bacterial colonies after microbial biostimulation process

In the first seven days of sample incubation, there was no significant difference between treatments. Differences began to occur after 21 days of incubation, with the largest number of treatment colonies $50 \%$. This is due to the sources of nutrients in this treatment, which were essential for microbial growth, being an easy source for assimilation. Even with $100 \%$ of soil sample containing metals, there was still microbial growth, because the added nutrient sources were sufficient for the microbiota to overcome the stress of the environment.

After 21 days of incubation, there was a decrease in colonies growth, because there was a decrease in the amount of nutritional source for the native microorganisms.

The same can be observed in Figure 2, microbial respiration evaluation. From the moment that there was the addition of nutrient sources, microbial biostimulation, resulted in stimulation of microbial activity. Even in the face of stress arising from the presence of 


\section{Macrothink}

metals in the soil, over the days, the microbiota managed to overcome the negative effects present in the environment.

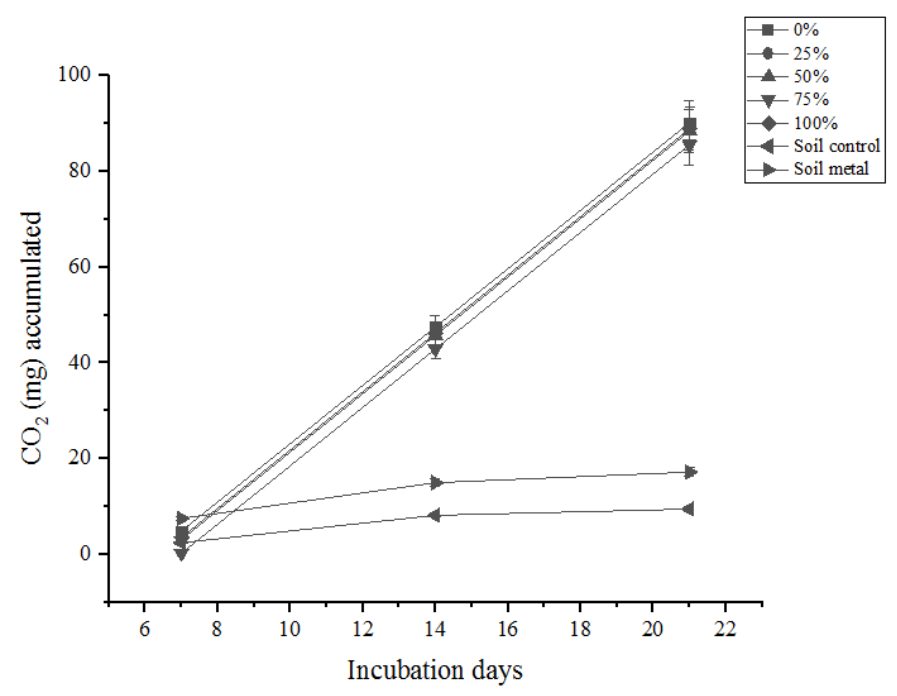

Figure 2. Quantification of $\mathrm{CO}_{2}$ accumulation after microbial biostimulation process

Without the biostimulation performed, microbial activity was impaired over the days, due to the presence of metals in the soil, harming the local ecosystem, because the microbiota is responsible for nutrient cycling in the environment.

Microbial biostimulation was essential from control soil, without the presence of metals to samples containing metal tailings from the mining disruption (100\%), favoring the beginning of the restoration of equilibrium of that affected site. The same was observed by Roy et al. (2018), when studying the effect of microbial biostimulation in soils affected by hydrocarbons, being fundamental for the aid of contaminant biodegradation.

Régo et al. (2014), studying the effects of ametryne herbicide on microbial activity, observed that the addition of biofertilizer was essential for microbiota biostimulation, favoring increased microbial respiration. The same observed effect was observed by causing biostimulation by the addition of Tween 80 surfactant, which is rich in carbon source (Régo et al., 2018).

\section{Conclusion}

Thus, it is important to add nutritional sources in contaminated sites, in order to favor the restoration of respiratory activities and increase the population of impacted microorganisms.

\section{References}

Andrews, S. S., Karlen, D. L., \& Cambardella, C. A. (2004). The soil management assessment framework: a quantitative soil quality evaluation method. Soil Science Society America Journal, 68, 1945-1962. https://doi.org/10.2136/sssaj2004.1945

Armenise, E., Redmile-Gordon, M. A., Stellaci, A. M., Ciccarese, A., \& Rubino, P. (2013). 
Developing a soil quality index to compare soil fitness for agricultural use under diferent managements in the Mediterranean environment. Soil Tillage Reseach, 30, 91-98. https://doi.org/10.1016/j.still.2013.02.013

Aseri, G. K., Jain, N., Panwar, J., Pao, A. V., \& Meghwal, P. R. (2008). Biofertilizers improve plant growth, fruit yield, nutrition, metabolism and rhizosphere enzyme activities of Pomegranate (Punica granatum L.) in Indian Thar Desert. Scientia Horticulturae, 117, 130-135. https://doi.org/10.1016/j.scienta.2008.03.014

Baretta, D., Mafra, A. L., Santos, J. C. P., Amarante, C. V. T., \& Bertol, I. (2006). Análise multivariada da fauna edáfica em diferentes sistemas de preparo e cultivo do solo. Pesquisa Agropecuária Brasileira, 41, 1675-1679. https://doi.org/10.1590/S0100-204X2006001100 014

Baretta, D., Santos, J. C. P., Segat, J. C., Geremia, E. V.,Filho, L. C. I. O., \& Alves, M. V. (2011). Fauna edáfica e qualidade do solo. Tópicos em Ciência do Solo, 7, 117-170.

Bartha, R., \& Pramer, D. (1965). Features of flask and method for measuring the persistence and biological effects of pesticides in soil. Soil Science, 100, 68-70. https://doi.org/10.1097/ 00010694-196507000-00011

Chen, M. Xu, P., Zeng, G., Yang, C., Huang, D., \& Zhang, J. (2015). Bioremediation of soils contaminated with polycyclic aromatic hydrocarbons, petroleum, pesticides, chlorophenols and heavy metals by composition: Applications, microbes and future research needs. Biotechnology Advances, 33, 745-755. https://doi.org/10.1016/j.biotechadv.2015.05.003

D’andrea, P. A. (2002). Processo de compostagem líquida contínua- CLC e Biofertilizante. Microbiol Indústria e Comércio LTDA. (BR/SP). No 2099 Registro PI0207342-0 A2

Duval, M. E., Galantini, J. A., Iglesias, J. O., Canelo, S., Martinez, J. M., \& Wall, L. (2013). Analysis of organic fractions as indicators of soil quality under natural and cultivated systems. Soil \& Tillage Research, 131, 11-19. https://doi.org/10.1016/j.still.2013.03.001

Jilani, G., Akram, A., Ali, R. M., Hafeez, F. Y., Shamsi, I. H., Chaudhry, A. N., \& Chaudhry, A. G. (2007). Enhancing crop growth, nutrients availability, economics and beneficial rhizosphere microflora through organic and biofertilizers. Annals of Microbiology, 57, 177-183. https://doi.org/10.1007/BF03175204

Kladivko, E. J., Helmes, L. J., Abendroth, D., Herzmann, R., L. A, M. J., \& Castellano, D. S. (2014). Standardized research protocols enable transdisciplinary research of climate variation impacts in corn production systems. Journal of soil and water conservation, 69, 532-542. https://doi.org/10.2489/jswc.69.6.532

Lehmann, J., Rillig, M. C., Thies, J., Masiello, C. A., Hockaday, W. C., \& Crowly, D. (2011). Biochar effects on soil biota- A review. Soil Biology \& Biochemistry, 43, 1812-1836. https://doi.org/10.1016/j.soilbio.2011.04.022

Li, Z., Ma, Z., Kwijp, J. V. D., Yan, Z., \& Huang, L. (2014). A review of soil heavy metal pollution from mines in China: Pollution and health risk assessment. Science of the Total Environment, 468-469, 843-853. https://doi.org/10.1016/j.scitotenv.2013.08.090

Medina, A. A., Adetutu, E. M., Aller, S., Weber, J., Patil, S. S., Sheppard, P. J., Ball, A. S., \& Juhasz, A. L. (2012). Comparison of indigenous and exogenous microbial populations during 
slurry phase biodegradation of long-term hydrocarbon-contaminated soil. Biodegradation, 23, 813-822. https://doi.org/10.1007/s10532-012-9563-8

Mohan, D., Saiswat, A., Ok, Y. S., \& Jr, C. U. P. (2014). Organic and inorganic contaminants removal from water with biochar, a renewable, low cost and sustainable adsorbent. A critical review. Bioresource Technology, 160, 191-202. https://doi.org/10.1016/j.biortech.2014.01.120

Rathnayake I. V. N., Megharaj M., Krishnamurti G. S. R., Bolan N. S., \& Naidu R. (2013). Heavy metal toxicity to bacteria - Are the existing growth media accurate enough to determine heavy metal toxicity? Chemosphere, 90, 1195-1200. https://doi.org/10.1016/j. chemosphere.2012.09.036

Régo, A. P. J., Mendes, K. F., Bidoia, E. D., \& Tornisielo, V. L. (2018). DCPIP and respirometry used in the understanding of ametryn biodegradation. Journal of Environment and Ecology, 9, 1-11. https://doi.org/10.5296/jee.v9i1.13962

Régo, A. P. J., Reganhan-Coneglian, C. M., Montagnolli, R. N., \& Bidoia, E. D. (2014). CO2 production of soil microbiota in the presence of ametryne and biofertilizer. Water Air Soil Pollution, 225, 1-6. https://doi.org/10.1007/s11270-014-2222-4

Roy, A., Dutta., A., Pal, S., Gupta, A., Sarkar, J., Chatterjee, A., Saha, A., Sarkar, P., Sar, P., $\&$ Kazy, S. K. (2018). Biostimulation and bioaugmentation of native microbial community accelerated bioremediation of oil refinery sludge. Biosource Technology, 253, 22-32. https://doi.org/10.1016/j.biortech.2018.01.004

Tchounwou, P. B., Yedjou, C. G., Patlolla, A. K., \& Sutton, D. J. (2012). Heavy metals toxicity and the environment. National Institutes of Health, 101, 133-164. https://doi.org/ 10.1007/978-3-7643-8340-4_6

Vessey, J. K. (2003). Plant growth promoting rhizobacteria as biofertilizers. Plant and soil, 255, 571-586. https://doi.org/10.1023/A:1026037216893

Wu, S. C., Cao, Z. H., Li, Z. G., Cheung, K. C., \& Wong, M. H. (2005). Effects of biofertilizer containing $\mathrm{N}$-fixer, $\mathrm{P}$ and $\mathrm{K}$ solubilizers and Am fungi on maize growth: a greenhouse trial. Geoderma, 125, 155-166. https://doi.org/10.1016/j.geoderma.2004.07.003

\section{Copyright}

Copyright for this article is retained by the author(s), with first publication rights granted to the journal.

This is an open-access article distributed under the terms and conditions of the Creative Commons Attribution license (http://creativecommons.org/licenses/by/4.0/). 